\title{
Vegetable oils affect the composition of lipoproteins in sea bream (Sparus aurata)
}

\author{
Maria José Caballero ${ }^{1 *}$, Bente E. Torstensen ${ }^{2}$, Lidia Robaina ${ }^{3}$, Daniel Montero ${ }^{3}$ and Marisol Izquierdo ${ }^{3}$ \\ ${ }^{1}$ Department of Comparative Pathology, Trasmontaña, s/n, 35416 Arucas, Las Palmas de Gran Canaria, Canary Islands, Spain \\ ${ }^{2}$ National Institute of Nutrition and Seafood Research, PO Box 2029 Nordnes, 5817 Bergen, Norway \\ ${ }^{3}$ Group Aquaculture Research. Instituto Canario de Ciencias Marinas, PO Box 56, 35200, Telde, Las Palmas de Gran Canaria, \\ Canary Islands, Spain
}

(Received 14 December 2005 - Revised 20 June 2006 - Accepted 21 June 2006)

\begin{abstract}
The aim of the present study was to determine the influence of the dietary fatty acid profile on the lipoprotein composition in sea bream fed different vegetable oils. Six experimental diets were formulated combining fish oil with three vegetable oils (soybean, rapeseed, linseed) in order to obtain $60-80 \%(\mathrm{w} / \mathrm{w})$ fish-oil replacement. VLDL, LDL and HDL in plasma samples were obtained by sequential centrifugal flotation. The lipid class, protein content and fatty acid composition of each lipoprotein fraction were analysed. HDL was the predominant lipoprotein in sea bream plasma containing the highest proportion of protein (34\%) and phosphatidylcholine. LDL presented a high content of cholesterol, whereas triacylglycerol comprised a larger proportion of VLDL. The lipid class of the lipoprotein fractions was affected by the dietary vegetable oils. Thus, a high dietary inclusion of soyabean and linseed oil (80\%) increased the cholesterol in HDL and LDL in comparison to fish oil. Similarly, the triacylglycerol concentration of VLDL was increased in fish fed $80 \%$ soyabean and linseed oils owing to the low $n$-3 highly unsaturated fatty acid content of these diets. Lipoprotein fatty acid composition easily responded to dietary fatty acid composition. VLDL was the fraction more affected by dietary fatty acid, followed by LDL and HDL. The $n-3$ highly unsaturated fatty acid content increased in the order VLDL less than LDL and less than HDL, regardless of dietary vegetable oils.
\end{abstract}

Sea bream: Lipoproteins: VLDL: LDL: HDL: Vegetable oils: Cholesterol: Triacylglycerols: Phosphatidylcholine: Sterol esters: $n$-3 highly unsaturated fatty acids

As in mammals, the transport of fatty acids and other lipid-soluble components to the peripheral tissues in fish is mediated mainly by lipoproteins. Exogenous lipids absorbed by the intestine are predominantly integrated into chylomicrons and VLDL (Sire et al. 1981; Caballero et al. 2003), whereas endogenous lipids are transported in VLDL, LDL and HDL (Sheridan, 1988; Babin \& Vernier, 1989; Iijima et al. 1995). Proteins and lipids integrated into the different lipoproteins interact with enzymes or cellular receptors, resulting in lipoprotein degradation or transformation, with the subsequent transfer of products from tissues to lipoproteins or vice versa. Initially, chylomicrons and VLDL-triacylglycerols (TAG) are hydrolysed by the enzyme lipoprotein lipase, releasing fatty acids that are up taken by adipose tissue for storage or by other organs, such as muscle, for oxidation (Auwerx et al. 1992). The withdrawal of the LDL particles is mainly mediated by specific extrahepatic LDL receptors (Brown \& Goldstein, 1997). One of the principal roles of HDL is to carry cholesterol from the peripheral cells to the liver. A key enzyme in this process is lecithin:cholesterol acyltransferase, responsible for transferring cholesterol and fatty acids from phosphatidylcholine to cholesterol esters on the surface of the HDL. Lecithin:cholesterol acyltransferase activity has been observed in the plasma of teleost fish (Black et al. 1985).

The lipid proportion and composition of each lipoprotein are affected by, among other factors, dietary composition (Sheridan et al. 1985). For instance, the fatty acid composition of lipoproteins is reported to be affected by dietary fatty acid composition in Atlantic salmon (Salmo salar; Lie et al. 1993; Torstensen et al. 2000, 2001). The increasing global demand on fish oil and the unpredictability of its production imposes limitations on the utilization of vegetable oils in commercial aqua feeds (Food \& Agriculture Organization, 1997). A partial replacement of fish oil by certain vegetable oils has, in several species, been proved to be feasible without affecting growth (Caballero et al. 2002; Bell et al. 2003; Regost et al. 2003; Izquierdo et al. 2003, 2005; Montero et al. 2005). Little information is, however, available on how these dietary fatty acids influence lipid transport in sea bream. Recent studies (Caballero et al. 2003, 2006) have reported that vegetable lipid sources affect intestinal TAG and phospholipid biosynthesis, interfering with the types of lipoprotein produced by the intestine of sea bream. In order to complete this information, an experiment was conducted to determine the influence of the dietary fatty 
acid profile on the lipoprotein composition in sea bream fed different vegetable oils.

\section{Material and methods}

Fish

The studies were carried out at the Instituto Canario de Ciencias Marinas (Canary Islands, Spain), and all fish were obtained from a local fish farm (ADSA, Canary Islands, Spain). Three hundred gilthead sea bream (Sparus aurata) with an average initial body weight of $10.06 \mathrm{~g}$ were randomly distributed in 100-litre polyethylene circular tanks (20 fish/ tank). Tanks were supplied with continuous seawater $(36 \%$ ) flow and aeration. The fish were fed under natural photoperiod conditions of approximately $12 \mathrm{~h} / 12 \mathrm{~h}$ dark light. The water temperature and dissolved $\mathrm{O}_{2}$ concentration during the experimental period ranged between 20.0 and $24.2{ }^{\circ} \mathrm{C}$ and 5.04 and $8.32 \mathrm{ppm}$, respectively. Fish were acclimatised to the experimental tanks and fed the control diet for 2 weeks before beginning the experiment. They were fed the experimental diets until apparent satiation three times a day, at 09.00, 12.00 and 15.00 hours, 6 days a week for 101 days. Each diet was assayed in triplicate tanks.

\section{Experimental diets}

Six isoenergetic and isonitrogenous experimental diets were formulated to contain $22 \%$ crude lipid and $45 \%$ crude protein. Whereas the control (100FO) diet contained anchovy oil as the only added lipid source, anchovy oil in all the other diets was partly replaced by vegetable oils (Table 1). Sixty per cent of the anchovy oil was replaced by either soyabean, rapeseed or linseed oil in diets 60SO, 60RO and 60LO, whereas $80 \%$ was replaced by either soyabean or linseed oil in diets $80 \mathrm{SO}$ and 80LO. Anchovy oil was included in all the diets at a level high enough to keep the content of $n-3$ highly unsaturated fatty acid (HUFA), with twenty or more carbon atoms and three or more double bonds, over $3 \%$ in order to meet the essential fatty acid requirements of this species (Montero et al. 1996).

An analysis of the fatty acid composition of the diets (Table 2) showed the highest saturated fatty acid and n-3
HUFA content in diet $100 \mathrm{FO}$, the highest linoleic acid $(18: 2 n-6)$ level in diets $60 \mathrm{SO}$ and $80 \mathrm{SO}$, the highest linolenic acid $(18: 3 n-3)$ in diets $60 \mathrm{LO}$ and $80 \mathrm{LO}$, and the highest oleic acid $(18: 1 n-9)$ concentration in diet 60RO. The dietary ratios of $n-3$ to $n-6$ differed between the experimental diets, mainly due to the different $18: 2 n-6$ content of the plant oils used, ranging from 1.4 in diet $100 \mathrm{FO}$ to 0.5 in diet $60 \mathrm{SO}$ and 0.3 in diet $80 \mathrm{SO}$. Diets $60 \mathrm{LO}$ and $80 \mathrm{LO}$ had an $n-3: n-6$ ratio higher than 2, mainly due to the higher $18: 3 n-3$ content. Diets $80 \mathrm{SO}$ and $80 \mathrm{LO}$ had the lowest $n$-3 HUFA content, particularly in terms of arachidonic acid (20:4n-6), EPA $(20: 5 n-3)$ and DHA $(22: 6 n-3)$.

\section{Sampling procedure}

The fish were sampled at the end of the feeding trial. The fish were fasted for $24 \mathrm{~h}$ prior to sampling. Twenty randomly sampled fish per tank were anaesthetised with chlorobutanol $(200 \mathrm{mg} / \mathrm{l})$. Blood was collected from the caudal veins using EDTA-containing Vacutainers (Becton Dickinson, Franklin Lakes, NJ, USA). Plasma was separated from the blood samples by centrifugation at $3000 \mathrm{rpm}$ for $10 \mathrm{~min}$. The twenty plasma samples from each tank were pooled into three samples (nine samples for each diet tested) and stored on ice $\left(4^{\circ} \mathrm{C}\right)$ until lipoprotein fractionation.

\section{Separation of lipoproteins}

VLDL, LDL and HDL in pooled plasma samples were obtained by sequential centrifugal flotation, as described by Lie et al. (1994), using a Pegasus 65 ultracentrifuge equipped with a 70Ti fixed-angle rotor (Beckman Coulter Inc., Fullerton, CA, USA). Centrifugation was carried out at $37500 \mathrm{rpm}$ and $4^{\circ} \mathrm{C}$. The density intervals were obtained by adding solid $\mathrm{KBr}$ (Warnick et al. 1979). The run times for lipoprotein separation were: $d<1.015 \mathrm{~g} / \mathrm{ml}$ over $20 \mathrm{~h}$ for VLDL; $1.015<d<1.085 \mathrm{~g} / \mathrm{ml}$ over $20 \mathrm{~h}$ for LDL; $1.085<d<1.21 \mathrm{~g} / \mathrm{ml}$ over $44 \mathrm{~h}$ for HDL. The different lipoprotein fractions obtained were weighed on an analytical balance (Mettler AJ100; Mettler Toledo S. A. E., L'Hospitalet de Llobregat, Barcelona) and stored at $-80^{\circ} \mathrm{C}$ until further analysis.

Table 1. Composition of experimental diets containing different lipid sources

\begin{tabular}{|c|c|c|c|c|c|c|}
\hline & \multicolumn{6}{|c|}{ Diet } \\
\hline & $100 \mathrm{FO}(\mathrm{g} / \mathrm{kg})$ & $60 S O(g / k g)$ & $60 \mathrm{RO}(\mathrm{g} / \mathrm{kg})$ & $60 \mathrm{LO}(\mathrm{g} / \mathrm{kg})$ & $80 \mathrm{SO}(\mathrm{g} / \mathrm{kg})$ & $80 \mathrm{LO}(\mathrm{g} / \mathrm{kg})$ \\
\hline Fish meal (LT) & $381 \cdot 3$ & $381 \cdot 3$ & $381 \cdot 3$ & $381 \cdot 3$ & $381 \cdot 3$ & $381 \cdot 3$ \\
\hline Corn gluten & $259 \cdot 8$ & 259.8 & $259 \cdot 8$ & $259 \cdot 8$ & 259.8 & $259 \cdot 8$ \\
\hline Wheat & $150 \cdot 7$ & $150 \cdot 7$ & $150 \cdot 7$ & $150 \cdot 7$ & $150 \cdot 7$ & $150 \cdot 7$ \\
\hline Lysine (99\%) & $7 \cdot 2$ & $7 \cdot 2$ & $7 \cdot 2$ & $7 \cdot 2$ & $7 \cdot 2$ & $7 \cdot 2$ \\
\hline Premix ${ }^{*}$ & 25 & 25 & 25 & 25 & 25 & 25 \\
\hline Anchovy oil & 176 & 70.4 & $70 \cdot 4$ & $70 \cdot 4$ & $35 \cdot 2$ & $35 \cdot 2$ \\
\hline Soyabean oil† & & $105 \cdot 6$ & & & $140 \cdot 8$ & \\
\hline Rapeseed oil† & & & $105 \cdot 6$ & & & \\
\hline Linseed oil† & & & & $105 \cdot 6$ & & $140 \cdot 8$ \\
\hline \multicolumn{7}{|l|}{ Composition } \\
\hline Crude lipids & $23 \cdot 74$ & $24 \cdot 15$ & 22.94 & $23 \cdot 19$ & $22 \cdot 59$ & $25 \cdot 48$ \\
\hline Crude protein & $47 \cdot 52$ & $48 \cdot 84$ & $48 \cdot 51$ & $48 \cdot 52$ & $49 \cdot 43$ & $48 \cdot 71$ \\
\hline
\end{tabular}

LT, low temperature.

* Premix of vitamins and minerals according to National Research Council (1993) recommendations for fish

$\dagger$ Crude vegetable oils. 
Table 2. Main fatty acid composition of diets containing fish oil in combination with different vegetable lipid sources

\begin{tabular}{|c|c|c|c|c|c|c|}
\hline & \multicolumn{6}{|c|}{ Diet } \\
\hline & $\begin{array}{c}100 \mathrm{FO}(\mathrm{g} / 100 \mathrm{~g} \\
\text { fatty acids) }\end{array}$ & $\begin{array}{c}60 S O(g / 100 \mathrm{~g} \\
\text { fatty acids) }\end{array}$ & $\begin{array}{c}\text { 60RO }(\mathrm{g} / 100 \mathrm{~g} \\
\text { fatty acids) }\end{array}$ & $\begin{array}{c}60 \mathrm{LO}(\mathrm{g} / 100 \mathrm{~g} \\
\text { fatty acids) }\end{array}$ & $\begin{array}{l}80 S O(g / 100 \mathrm{~g} \\
\text { fatty acids) }\end{array}$ & $\begin{array}{c}80 \mathrm{LO}(\mathrm{g} / 100 \mathrm{~g} \\
\text { fatty acids) }\end{array}$ \\
\hline $14: 0$ & $6 \cdot 21$ & $3 \cdot 18$ & $3 \cdot 11$ & 3.09 & $1 \cdot 10$ & 1.94 \\
\hline $16: 0$ & $18 \cdot 51$ & $15 \cdot 45$ & $12 \cdot 43$ & $12 \cdot 21$ & $14 \cdot 24$ & $10 \cdot 89$ \\
\hline $18: 0$ & $3 \cdot 18$ & $3 \cdot 21$ & 2.35 & 3.37 & $3 \cdot 30$ & 3.45 \\
\hline Sum saturated & $27 \cdot 90$ & $21 \cdot 84$ & $17 \cdot 89$ & $18 \cdot 67$ & $18 \cdot 64$ & $16 \cdot 28$ \\
\hline $16: 1 n-7$ & $6 \cdot 46$ & 3.41 & 3.39 & $3 \cdot 31$ & $2 \cdot 20$ & $2 \cdot 10$ \\
\hline $17: 1$ & $1 \cdot 28$ & 0.63 & 0.63 & 0.62 & 0.37 & 0.35 \\
\hline $18: 1 n-9$ & $16 \cdot 26$ & $18 \cdot 48$ & $36 \cdot 84$ & $17 \cdot 03$ & 21.07 & $18 \cdot 71$ \\
\hline $18: 1 n-7$ & 2.47 & $1 \cdot 84$ & ND & 1.54 & ND & ND \\
\hline $20: 1 n-9$ & 1.89 & 1.63 & 2.08 & 1.58 & 1.49 & 1.61 \\
\hline $22: 1 n-11$ & 1.95 & 1.49 & $2 \cdot 13$ & $2 \cdot 13$ & $2 \cdot 01$ & 1.78 \\
\hline $22: 1 n-9$ & 0.14 & 0.22 & 0.03 & 0.03 & 0.03 & 0.08 \\
\hline Sum monoenes & $30 \cdot 45$ & $27 \cdot 70$ & $45 \cdot 10$ & $26 \cdot 24$ & $27 \cdot 17$ & $24 \cdot 63$ \\
\hline $162 n-6$ & $1 \cdot 15$ & 0.60 & 0.57 & 0.58 & 0.37 & 0.36 \\
\hline $18: 3 n-6$ & 0.21 & 0.12 & 0.10 & 0.11 & 0.07 & 0.07 \\
\hline $20: 4 n-6$ & 0.54 & 0.34 & 0.33 & 0.36 & 0.25 & 0.23 \\
\hline $22: 3 n-6$ & 0.53 & 0.33 & 0.29 & 0.29 & 0.22 & 0.22 \\
\hline $22: 4 n-6$ & 0.25 & 0.21 & 0.17 & 0.18 & 0.16 & 0.15 \\
\hline Sum $n-6$ & $15 \cdot 75$ & $32 \cdot 88$ & $18 \cdot 50$ & $13 \cdot 81$ & 39.61 & $18 \cdot 69$ \\
\hline $16: 4 n-3$ & 1.85 & 0.88 & 0.85 & 0.88 & 0.44 & 0.44 \\
\hline $18: 3 n-3$ & 1.41 & $3 \cdot 24$ & $4 \cdot 64$ & $26 \cdot 72$ & 4.03 & $30 \cdot 63$ \\
\hline $18: 4 n-3$ & 1.43 & 0.79 & 0.76 & 0.78 & 0.48 & 0.54 \\
\hline $20: 4 n-3$ & 0.43 & 0.25 & 0.26 & 0.25 & 0.22 & 0.19 \\
\hline $20: 5 n-3$ & $11 \cdot 19$ & $5 \cdot 88$ & 5.84 & $6 \cdot 19$ & 3.73 & 3.79 \\
\hline $22: 4 n-3$ & 0.19 & 0.15 & 0.12 & 0.14 & 0.10 & 0.08 \\
\hline $22: 5 n-3$ & $1 \cdot 16$ & 0.75 & 0.63 & 0.79 & 0.50 & 0.45 \\
\hline $22: 6 n-3$ & 4.99 & $3 \cdot 20$ & $3 \cdot 26$ & 3.58 & $2 \cdot 36$ & 2.92 \\
\hline Sum $n-3$ & $22 \cdot 65$ & $15 \cdot 14$ & $16 \cdot 36$ & $39 \cdot 33$ & $11 \cdot 86$ & $39 \cdot 04$ \\
\hline Sum $n-3$ highly unsaturated fatty acids & $17 \cdot 96$ & $10 \cdot 23$ & $10 \cdot 11$ & $10 \cdot 95$ & $6 \cdot 91$ & $7 \cdot 43$ \\
\hline$n-3: n-6$ & 1.44 & 0.46 & 0.88 & $2 \cdot 85$ & 0.30 & $2 \cdot 09$ \\
\hline Lipids (\% DW) & $21 \cdot 14$ & $20 \cdot 70$ & $21 \cdot 83$ & $21 \cdot 83$ & $20 \cdot 93$ & $22 \cdot 58$ \\
\hline
\end{tabular}

ND, not detected.

\section{Analytical procedures}

Lipids from pooled samples were extracted with a chloroform-methanol $(2: 1, \mathrm{v}: \mathrm{v})$ mixture as described by Folch et al. (1957). Fatty acid methyl esters were obtained by transesterification with $1 \% \mathrm{H}_{2} \mathrm{SO}_{4}$ in $\mathrm{CH}_{3} \mathrm{OH}$ (Christie, 1982) using heneicosaenoic acid (10\% of total lipids) as an internal standard. Fatty acid methyl esters were purified by adsorption chromatography on $\mathrm{NH}_{2}$ sep-pack cartridges (Waters SA, Milford, MA, USA) as decribed by Fox (1990), and separated and quantified by GLC following the conditions described by Izquierdo et al. (1990).

The lipid classes of each lipoprotein fraction were separated by high-precision TLC into sterol esters, TAG, cholesterol and phosphatidylcholine, phosphatidylethanolamine, phosphatidylinositol and phosphatidylserine, and quantified by a flame ionisation detector system (Iatroscan MK-5, Iatron Laboratories Inc., Tokyo, Japan) according to the method described by Rønnestad et al. (1995). The total protein content of each lipoprotein fraction was determined by Lowry assay (Lowry et al. 1951).

\section{Statistics}

Results were expressed as means and standard deviations. Data were compared by ANOVA, and Tukey's test for comparison of means was applied $(P<0 \cdot 05)$. When variances were not normally distributed, the Kruskal-Wallis non-parametric test was applied to the data, and for comparison of medians, the Box and Whisker-notched test was applied (Sokal \& Rolf, 1995).

\section{Results}

The amount of each lipoprotein fraction per gram of sea bream plasma was 264 (SD 37.6) $\mathrm{mg} / \mathrm{g}$ for HDL, 194.2 (SD 43.7) $\mathrm{mg} / \mathrm{g}$ for VLDL and only 131.6 (SD 41.5) $\mathrm{mg} / \mathrm{g}$ for LDL.

\section{Total protein and lipid content}

Table 3 shows the total protein and lipid content of the lipoprotein fractions expressed as milligrams of protein or lipid per gram of lipoprotein fraction. No significant differences were found in the total protein (average $5.4 \mathrm{mg}$ protein/g HDL) or lipid (average $11.2 \mathrm{mg}$ lipid/g HDL) contents of the HDL fraction among fish fed the experimental diets. In the LDL fraction, the protein content was similar in all the experimental groups (average $0.4 \mathrm{mg}$ protein $/ \mathrm{g}$ LDL), whereas a higher content of total lipids was present in fish fed the $80 \mathrm{SO}$ and $80 \mathrm{LO}(1.2 \mathrm{mg}$ lipid/g LDL) diets, fish fed 100FO showing the lowest lipid content $(0.4 \mathrm{mg}$ lipid/g LDL). No significant differences were found in the total protein (average $0.4 \mathrm{mg}$ protein/g VLDL) for the VLDL fraction among fish 
Table 3. Total protein and lipid content of the lipoprotein fractions of sea bream fed the experimental diets (Means and standard deviations; three samples from each tank, nine for each experimental diet)

\begin{tabular}{|c|c|c|c|c|c|c|c|c|c|c|c|c|}
\hline \multirow[b]{3}{*}{ Diets } & \multicolumn{6}{|c|}{ Protein content } & \multicolumn{6}{|c|}{ Lipid content } \\
\hline & \multicolumn{2}{|c|}{$\begin{array}{c}\text { mg protein/g } \\
\text { HDL }\end{array}$} & \multicolumn{2}{|c|}{$\begin{array}{l}\text { mg protein/g } \\
\text { LDL }\end{array}$} & \multicolumn{2}{|c|}{$\begin{array}{l}\text { mg protein/g } \\
\text { VLDL }\end{array}$} & \multicolumn{2}{|c|}{$\begin{array}{c}\text { mg lipid/g } \\
\text { HDL }\end{array}$} & \multicolumn{2}{|c|}{$\begin{array}{l}\mathrm{mg} \mathrm{lipid} / \mathrm{g} \\
\text { LDL }\end{array}$} & \multicolumn{2}{|c|}{$\begin{array}{l}\mathrm{mg} \mathrm{lipid} / \mathrm{g} \\
\text { VLDL }\end{array}$} \\
\hline & Mean & SD & Mean & SD & Mean & SD & Mean & $\mathrm{SD}$ & Mean & SD & Mean & SD \\
\hline 100FO & $5 \cdot 0$ & $1 \cdot 2$ & 0.3 & 0.2 & 0.2 & 0.1 & $9 \cdot 3$ & $2 \cdot 7$ & 0.4 & $0 \cdot 1^{\mathrm{a}}$ & 0.8 & $0.2^{a}$ \\
\hline 6050 & $5 \cdot 3$ & $1 \cdot 2$ & 0.3 & 0.1 & 0.3 & 0.2 & $11 \cdot 0$ & $1 \cdot 1$ & 0.9 & $0 \cdot 2^{b c}$ & 1.0 & $0.2^{\mathrm{ab}}$ \\
\hline $60 \mathrm{RO}$ & $5 \cdot 6$ & 0.8 & 0.4 & 0.1 & 0.4 & 0.3 & $12 \cdot 3$ & 1.4 & 0.9 & $0.3^{b c}$ & 1.2 & $0.2^{a b}$ \\
\hline 60LO & $5 \cdot 2$ & 0.1 & 0.4 & 0.1 & 0.4 & 0.1 & $11 \cdot 3$ & 0.4 & 0.7 & $0 \cdot 1^{\mathrm{b}}$ & 1.3 & $0 \cdot 2^{a b}$ \\
\hline $80 S O$ & $5 \cdot 6$ & 0.6 & 0.5 & 0.2 & 0.4 & 0.2 & $12 \cdot 3$ & $1 \cdot 8$ & $1 \cdot 2$ & $0 \cdot 2^{\mathrm{cd}}$ & 1.3 & $0 \cdot 1^{\mathrm{ab}}$ \\
\hline 80LO & $5 \cdot 3$ & 0.8 & 0.3 & 0.1 & 0.5 & 0.3 & $10 \cdot 7$ & 0.9 & $1 \cdot 2$ & $0.3^{d}$ & 1.8 & $0 \cdot 1^{\mathrm{b}}$ \\
\hline
\end{tabular}

Superscript letters in the same row denote significantly different $(P \leq 0.05)$.

fed the experimental diets, but the lowest content of total lipid for this fraction was again found in fish fed diet $100 \mathrm{FO}$ (0.8 mg lipid/g VLDL).

\section{Lipid class composition}

The lipid class composition and percentage of protein in each lipoprotein fraction are shown in Fig. 1 and expressed as $\mathrm{g}$ lipid/g protein. An increase in the neutral lipid (sterol esters, TAG, cholesterol) content of the lipoproteins occurred concomitantly with a decreased protein content and density of lipoproteins (VLDL $<$ LDL $<$ HDL) for all the experimental diets tested. Phosphatidylcholine was the major phospholipids in all lipoprotein fractions, whereas only trace levels of the other glycerophospholipids (phosphatidylethanolamine, phosphatidylinositol, phosphatidylserine) were found. In VLDL, TAG comprised a larger proportion than the other fractions. The proportion of sterol esters was higher in the lipid of LDL than in HDL. HDL consisted mainly of protein (34\%) and phosphatidylcholine.

The lipid class composition of the different lipoprotein fractions expressed in $\mathrm{mg}$ lipid class/g plasma was affected by the experimental diets. In HDL (Fig. 2), fish fed diet $100 \mathrm{FO}$ had the lowest TAG content, being significantly different $(P<0.05)$ from that of fish fed diet 80 SO.

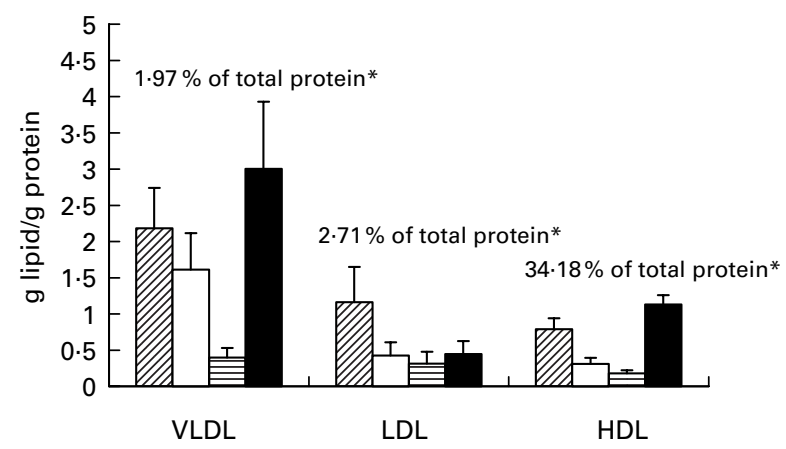

Fig. 1. Lipid class composition (g lipid/g protein) of VLDL, LDL and HDL from sea bream fed the experimental diets for $101 \mathrm{~d}$ (means and standard deviations). *Amount of protein in the lipoprotein fraction, calculated as (amount of protein in the lipoprotein fraction) / (amount of protein in VLDL + LDL + HDL + rest) $\times 100 \%$. Sterol esters; $\square$, Triacylglycerol; 目, Cholesterol; $\mathbf{\square}$, Phosphatidylcholine.
In addition, these latter fish presented the highest cholesterol content $(P<0.05)$. No differences were found in the sterol esters and phosphatidylcholine content among fish fed the different experimental diets. In LDL (Fig. 3), fish fed the $100 \mathrm{FO}$ diet showed the lowest level of TAG, cholesterol and phosphatidylcholine in comparison to the other experimental groups. High levels of cholesterol and phosphatidylcholine were found in fish fed diets $80 \mathrm{SO}$ and 80LO. In VLDL (Fig. 4), lipid classes showed a large variation between the different experimental groups. Thus, fish fed the 60RO diet presented markedly high sterol esters content in comparison to other fish. In addition, fish fed the 100FO diet showed the lowest level of cholesterol, this being significantly $(P<0.05)$ different from those of the other fish, except for those fed 60RO. Finally, the highest values of TAG were found in fish fed diets $80 \mathrm{SO}$ and $80 \mathrm{LO}$, values being significantly different from those of fish fed diets 100FO and 60RO.

\section{Fatty acid composition}

Table 4 shows the fatty acid composition of the VLDL fraction. The dietary influence of the composition of this fraction was demonstrated by the high level of $18: 1 n-9(30 \%)$ in the 60RO fish, $18: 2 n-6(21 \%$ and $26 \%)$ in the 60 SO and 80 SO fish, and $18: 3 n-3(12 \%$ and $18 \%)$ in the 60LO and $80 \mathrm{LO}$ fish. The highest levels of $n-3$ HUFA were found in fish fed diet $100 \mathrm{FO}$ $(P<0.05)$, particularly due to the high content of DHA.

The LDL fraction (Table 5) was characterised by high levels of saturated fatty acid, particularly 16:0, in comparison with VLDL. Dietary fatty acid composition was also reflected in the contents of oleic, linoleic and linolenic acids, although to a lesser extent than those found in VLDL fraction. The DHA content of the LDL fraction was also elevated in all experimental groups, irrespective of dietary content. The HDL fatty acid composition (Table 6) in particular was characterised by a markedly high $n-3$ HUFA content in all experimental groups, with values ranging from $24.6 \%$ (80SO fish) to $38.8 \%$ (100FO fish), mainly due to the high level of DHA. In addition, this fraction also had a higher content of arachidonic acid $(20: 4 n-6)$ in comparison with the other lipoprotein fractions. The HDL content of $18: 1 n-9 ; 18: 2 n-6$ and $18: 3 n-3$ reflected the dietary composition, although there was a considerable reduction in fatty acids of 18 carbons in 


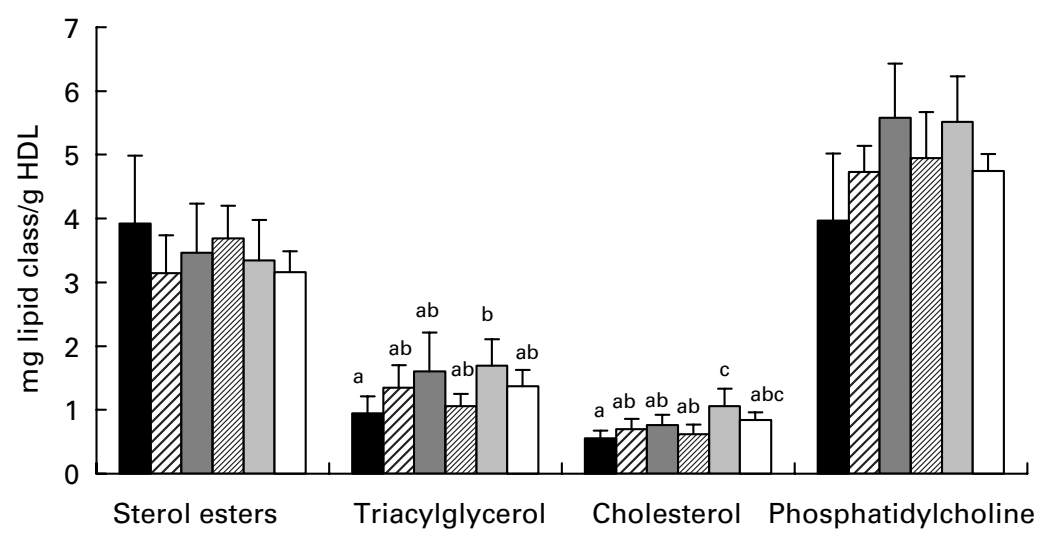

Fig. 2. HDL lipid class composition from sea bream fed the experimental diets (means and standard deviations; three samples from each tank, nine for each experimental diet). For the diet groups, mean values with unlike superscript letters were significantly different $(P \leq 0.05)$. Diets: $\square, 100 \mathrm{FO} ; \square, 60 S O$; $\square, 60 \mathrm{RO}$; $\square$, 60LO; $\square, 80 \mathrm{SO} ; \square, 80 \mathrm{LO}$.

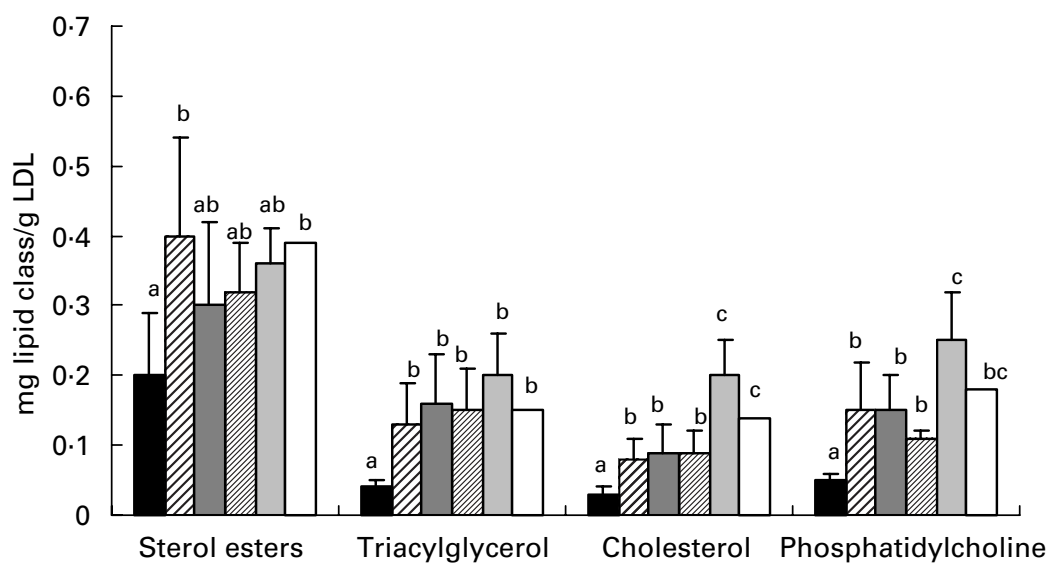

Fig. 3. LDL lipid class composition from sea bream fed the experimental diets (means and standard deviations; three samples from each tank, nine for each experimental diet). For the diet groups, mean values with unlike superscript letters were significantly different $(P \leq 0.05)$. Diets: $\mathbf{\square}, 100 \mathrm{FO} ; \boldsymbol{Z}, 60 \mathrm{SO} ; \square, 60 \mathrm{RO}$; $\square$, 60LO; $\square, 80 S O ; \square, 80 \mathrm{LO}$.

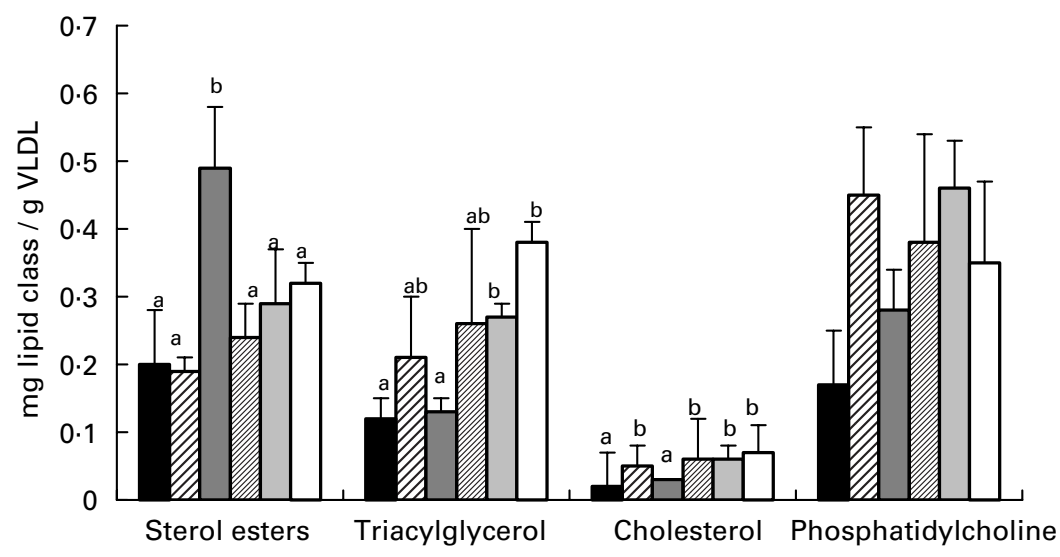

Fig. 4. VLDL lipid class composition from sea bream fed the experimental diets (means and standard deviations; three samples from each tank, nine for each experimental diet). For the diet groups, mean values with unlike superscript letters were significantly different $(P \leq 0.05)$. Diets: $\mathbf{\square}, 100 \mathrm{FO} ; \mathbb{Z}, 60 \mathrm{SO} ; \square, 60 \mathrm{RO} ; \square$, 60LO; $\square$, 80SO; $\square, 80$ LO. 
Table 4. Fatty acid composition of VLDL from sea bream fed the experimental diets for 12 weeks (Means and standard deviations; three samples from each tank, nine for each experimental diet)

\begin{tabular}{|c|c|c|c|c|c|c|c|c|c|c|c|c|}
\hline & \multicolumn{12}{|c|}{ Diet } \\
\hline & \multicolumn{2}{|c|}{$\begin{array}{c}100 \mathrm{FO} \\
\text { (g/100 g fatty } \\
\text { acids) }\end{array}$} & \multicolumn{2}{|c|}{$\begin{array}{c}60 \mathrm{SO} \\
\text { (g/100 g fatty } \\
\text { acids) }\end{array}$} & \multicolumn{2}{|c|}{$\begin{array}{c}60 \mathrm{RO} \\
\text { (g/100 g fatty } \\
\text { acids) }\end{array}$} & \multicolumn{2}{|c|}{$\begin{array}{c}60 \mathrm{LO} \\
\text { (g/100 g fatty } \\
\text { acids) }\end{array}$} & \multicolumn{2}{|c|}{$\begin{array}{c}80 \mathrm{SO} \\
\text { (g/100 g fatty } \\
\text { acids) }\end{array}$} & \multicolumn{2}{|c|}{$\begin{array}{c}80 \mathrm{LO} \\
\text { (g/100 g fatty } \\
\text { acids) }\end{array}$} \\
\hline & Mean & SD & Mean & SD & Mean & SD & Mean & SD & Mean & SD & Mean & SD \\
\hline $14: 0$ & $4 \cdot 3$ & 0.3 & $2 \cdot 4$ & 0.2 & $2 \cdot 2$ & 0.4 & $2 \cdot 2$ & 0.1 & $2 \cdot 2$ & 0.8 & $2 \cdot 2$ & 0.8 \\
\hline $18: 0$ & 8.0 & $2 \cdot 0$ & 11.5 & $4 \cdot 2$ & $7 \cdot 8$ & 0.8 & $8 \cdot 2$ & $3 \cdot 2$ & $10 \cdot 0$ & $5 \cdot 0$ & $8 \cdot 8$ & 0.1 \\
\hline Sum saturated & $30 \cdot 3$ & $4 \cdot 3^{a}$ & $37 \cdot 9$ & $9 \cdot 4^{\mathrm{a}}$ & $25 \cdot 1$ & $1 \cdot 8^{\mathrm{a}}$ & $26 \cdot 8$ & $5 \cdot 3^{a}$ & $26 \cdot 7$ & $8 \cdot 9^{a}$ & $28 \cdot 3$ & $0.7^{\mathrm{a}}$ \\
\hline $16: 1 n-7$ & $6 \cdot 0$ & $1 \cdot 1$ & $2 \cdot 7$ & 0.3 & $3 \cdot 1$ & 1.0 & $3 \cdot 0$ & 0.3 & $2 \cdot 4$ & 0.4 & $2 \cdot 4$ & 0.5 \\
\hline $18: 1 n-9$ & $19 \cdot 0$ & $1 \cdot 2^{\mathrm{a}}$ & $17 \cdot 9$ & $2 \cdot 8^{\mathrm{a}}$ & $30 \cdot 0$ & $3 \cdot 1^{\mathrm{b}}$ & $20 \cdot 2$ & $1 \cdot 0^{\mathrm{a}}$ & $19 \cdot 8$ & $3 \cdot 9^{a}$ & $19 \cdot 7$ & $1 \cdot 2^{\mathrm{a}}$ \\
\hline $18: 1 n-7$ & 3.4 & 0.3 & $2 \cdot 2$ & 0.1 & 3.0 & 0.6 & 2.4 & 0.6 & $2 \cdot 0$ & 0.4 & $2 \cdot 1$ & 0.4 \\
\hline $22: 1 n-11$ & $1 \cdot 3$ & 0.1 & 0.8 & 0.1 & 1.6 & 0.4 & 0.5 & 0.0 & 0.8 & 0.4 & $1 \cdot 2$ & 0.1 \\
\hline $22: 1 n-9$ & 0.4 & 0.0 & 0.3 & 0.1 & ND & & ND & & 0.7 & 0.4 & 0.4 & 0.0 \\
\hline Sum monoenes & $30 \cdot 1$ & $2 \cdot 3^{a b}$ & 23.9 & $2 \cdot 7^{a}$ & $37 \cdot 7$ & $5 \cdot 1^{b}$ & $26 \cdot 0$ & $2 \cdot 3^{a b}$ & $25 \cdot 7$ & $4 \cdot 2^{\mathrm{a}}$ & $26 \cdot 0$ & $1.4^{\mathrm{ab}}$ \\
\hline Sum $n-6$ & $8 \cdot 8$ & $0.9^{\mathrm{a}}$ & $21 \cdot 5$ & $6 \cdot 1^{\mathrm{ab}}$ & $19 \cdot 8$ & $1.5^{\mathrm{ab}}$ & $19 \cdot 0$ & $1.9^{\mathrm{ab}}$ & $26 \cdot 6$ & $4 \cdot 4^{\mathrm{b}}$ & $13 \cdot 0$ & $1 \cdot 3^{\mathrm{a}}$ \\
\hline $18: 3 n-3$ & 0.9 & $0.3^{\mathrm{a}}$ & 1.8 & $0 \cdot 5^{a}$ & $3 \cdot 1$ & $0 \cdot 3^{a b}$ & $12 \cdot 3$ & $0.6^{c}$ & $4 \cdot 0$ & $2 \cdot 5^{a b}$ & $17 \cdot 9$ & $0.7^{d}$ \\
\hline $20: 5 n-3$ & $11 \cdot 3$ & $0 \cdot 2^{\mathrm{a}}$ & $4 \cdot 1$ & $0 \cdot 1^{b}$ & $4 \cdot 3$ & $0 \cdot 1^{\mathrm{b}}$ & $4 \cdot 6$ & $0.6^{\mathrm{b}}$ & $3 \cdot 3$ & $0 \cdot 3^{\mathrm{b}}$ & 3.4 & $0 \cdot 2^{b}$ \\
\hline $22: 5 n-3$ & $4 \cdot 4$ & 0.1 & $2 \cdot 0$ & 0.0 & $2 \cdot 4$ & 0.0 & $2 \cdot 3$ & 0.5 & $2 \cdot 1$ & 0.3 & 1.7 & 0.4 \\
\hline $22: 6 n-3$ & 14.5 & $2 \cdot 5^{\mathrm{a}}$ & $8 \cdot 3$ & $0.3^{\mathrm{a}}$ & $10 \cdot 2$ & $1 \cdot 0^{\mathrm{a}}$ & $9 \cdot 6$ & $0.5^{\mathrm{a}}$ & 8.5 & $2 \cdot 5^{\mathrm{a}}$ & 9.5 & $0.7^{\mathrm{a}}$ \\
\hline Sum $n-3$ & $31 \cdot 1$ & $1.9^{\mathrm{a}}$ & $16 \cdot 3$ & $0.7^{b}$ & $20 \cdot 0$ & $1 \cdot 8^{\mathrm{b}}$ & $28 \cdot 8$ & $1 \cdot 1^{\mathrm{c}}$ & $18 \cdot 0$ & $0.4^{\mathrm{b}}$ & 32.5 & $0.7^{d}$ \\
\hline Sum $n-3$ highly unsaturated fatty acids & $30 \cdot 2$ & $1 \cdot 7^{\mathrm{a}}$ & $14 \cdot 8$ & $0.2^{b}$ & $16 \cdot 9$ & $2 \cdot 0^{\mathrm{b}}$ & $16 \cdot 5$ & $0.6^{\mathrm{b}}$ & $14 \cdot 0$ & $2 \cdot 7^{\mathrm{b}}$ & $15 \cdot 0$ & $1 \cdot 1^{\mathrm{b}}$ \\
\hline
\end{tabular}

Superscript letters in the same row denote significantly different $(P \leq 0.05)$.

ND, not detected.

Table 5. Fatty acid composition of LDL from sea bream fed the experimental diets for 12 weeks (Means and standard deviations; three samples from each tank, nine for each experimental diet)

\begin{tabular}{|c|c|c|c|c|c|c|c|c|c|c|c|c|}
\hline & \multicolumn{12}{|c|}{ Diet } \\
\hline & \multicolumn{2}{|c|}{$\begin{array}{c}100 \mathrm{FO} \\
\text { (g } / 100 \mathrm{~g} \text { fatty } \\
\text { acids) }\end{array}$} & \multicolumn{2}{|c|}{$\begin{array}{c}60 \mathrm{SO} \\
\text { (g /100 g fatty } \\
\text { acids) }\end{array}$} & \multicolumn{2}{|c|}{$\begin{array}{c}60 \mathrm{RO} \\
\text { (g /100 g fatty } \\
\text { acids) }\end{array}$} & \multicolumn{2}{|c|}{$\begin{array}{c}60 \mathrm{LO} \\
\text { (g /100 g fatty } \\
\text { acids) }\end{array}$} & \multicolumn{2}{|c|}{$\begin{array}{c}80 \mathrm{SO} \\
\text { (g /100 g fatty } \\
\text { acids) }\end{array}$} & \multicolumn{2}{|c|}{$\begin{array}{c}80 \mathrm{LO} \\
\text { (g /100 g fatty } \\
\text { acids) }\end{array}$} \\
\hline & Mean & $\mathrm{SD}$ & Mean & $\mathrm{SD}$ & Mean & SD & Mean & SD & Mean & SD & Mean & SD \\
\hline $14: 0$ & 3.9 & $1 \cdot 1$ & $1 \cdot 8$ & 0.4 & $1 \cdot 8$ & 0.6 & 1.9 & 0.5 & $1 \cdot 7$ & 0.2 & 1.6 & 0.3 \\
\hline $18: 0$ & 8.9 & 1.0 & $9 \cdot 9$ & 0.7 & $8 \cdot 3$ & 0.6 & 9.5 & 1.0 & $13 \cdot 0$ & $2 \cdot 2$ & 10.5 & $1 \cdot 2$ \\
\hline Sum saturated & $38 \cdot 8$ & $2.9^{a}$ & 38.4 & $3 \cdot 8^{a}$ & $30 \cdot 6$ & $5 \cdot 5^{\mathrm{ab}}$ & 24.9 & $3 \cdot 1^{\mathrm{b}}$ & 38.6 & $4 \cdot 1^{a}$ & 33.6 & $4 \cdot 7^{\mathrm{ab}}$ \\
\hline $16: 1 n-7$ & 4.4 & 0.1 & 2.2 & 0.0 & 3.9 & 0.1 & $3 \cdot 0$ & 0.2 & 1.6 & 0.2 & 1.9 & 0.1 \\
\hline $18: 1 n-9$ & 14.9 & $0.9^{a}$ & $15 \cdot 0$ & $2 \cdot 6^{a}$ & $26 \cdot 0$ & $0.9^{b}$ & 20.5 & $1.5^{a b}$ & $12 \cdot 8$ & $2 \cdot 8^{a}$ & $16 \cdot 2$ & $1.0^{\mathrm{a}}$ \\
\hline $18: 1 n-7$ & $2 \cdot 7$ & 0.4 & $2 \cdot 0$ & 0.2 & $9 \cdot 4$ & $2 \cdot 0$ & $2 \cdot 4$ & 0.2 & 1.6 & 0.3 & $1 \cdot 7$ & 0.1 \\
\hline $20: 1 n-9$ & 1.4 & 0.4 & 1.0 & 0.1 & 1.5 & 0.4 & $1 \cdot 3$ & 0.1 & 0.9 & 0.2 & $1 \cdot 2$ & 0.2 \\
\hline $22: 1 n-11$ & $2 \cdot 7$ & 2.5 & 0.6 & 0.0 & 0.8 & 0.5 & 0.9 & 0.0 & 0.6 & 0.1 & 0.9 & 0.2 \\
\hline $22: 1 n-9$ & 0.5 & 0.1 & 0.5 & 0.1 & 0.7 & 0.0 & ND & & 0.4 & $0 \cdot 1$ & 0.5 & 0.0 \\
\hline Sum monoenes & $26 \cdot 6$ & $1 \cdot 4^{\mathrm{ab}}$ & $21 \cdot 3$ & $3 \cdot 2^{\mathrm{a}}$ & $37 \cdot 2$ & $6 \cdot 3^{\mathrm{b}}$ & $28 \cdot 1$ & $1 \cdot 7^{\mathrm{ab}}$ & $17 \cdot 9$ & $3 \cdot 6^{\mathrm{a}}$ & $22 \cdot 3$ & $1 \cdot 2^{\mathrm{a}}$ \\
\hline $20: 4 n-6$ & 0.3 & $0.0^{\mathrm{a}}$ & 0.8 & $0.0^{\mathrm{a}}$ & ND & & ND & & $1 \cdot 1^{\mathrm{a}}$ & 0.1 & 0.7 & $0.5^{a}$ \\
\hline $22: 4 n-6$ & ND & & 0.3 & 0.0 & ND & & 0.6 & 0.1 & 0.5 & 0.1 & 0.3 & 0.2 \\
\hline Sum $n-6$ & 3.9 & $1 \cdot 2^{\mathrm{a}}$ & $15 \cdot 9$ & $2 \cdot 2^{\mathrm{b}}$ & $10 \cdot 8$ & $2 \cdot 6^{a b}$ & $9 \cdot 8$ & $1.9^{a b}$ & $18 \cdot 5$ & $4 \cdot 1^{a b}$ & 11.7 & $2 \cdot 6^{\mathrm{b}}$ \\
\hline $18: 3 n-3$ & 0.4 & $0 \cdot 1^{\mathrm{a}}$ & 1.3 & $0 \cdot 1^{a}$ & 1.6 & $0 \cdot 3^{a}$ & $13 \cdot 0$ & $2 \cdot 0^{\mathrm{C}}$ & $1 \cdot 2$ & $0.4^{a}$ & $13 \cdot 7$ & $1 \cdot 1^{\mathrm{c}}$ \\
\hline $20: 4 n-3$ & 0.6 & $0 \cdot 1$ & ND & & ND & & 0.6 & 0.0 & 0.3 & 0.1 & 0.6 & 0.1 \\
\hline $20: 5 n-3$ & $10 \cdot 1$ & $1.9^{\mathrm{a}}$ & $5 \cdot 6$ & $1 \cdot 0^{\mathrm{b}}$ & $5 \cdot 6$ & $0.6^{\mathrm{b}}$ & $6 \cdot 6$ & $0.4^{\mathrm{ab}}$ & 3.9 & $0.1^{\mathrm{b}}$ & 4.6 & $0.6^{\mathrm{b}}$ \\
\hline $22: 5 n-3$ & 3.7 & 0.3 & 2.5 & 0.4 & 1.9 & 0.0 & $3 \cdot 1$ & $0 \cdot 2$ & 1.8 & 0.3 & $2 \cdot 0$ & $0 \cdot 1$ \\
\hline $22: 6 n-3$ & 14.5 & $1 \cdot 8^{\mathrm{a}}$ & $13 \cdot 3$ & $3 \cdot 0^{\mathrm{a}}$ & $12 \cdot 3$ & $3 \cdot 0^{\mathrm{a}}$ & $13 \cdot 7$ & $2 \cdot 3^{\mathrm{a}}$ & $12 \cdot 4$ & $0 \cdot 1^{\mathrm{a}}$ & $14 \cdot 5$ & $1 \cdot 6^{\mathrm{a}}$ \\
\hline Sum $n-3$ & $29 \cdot 3$ & $4 \cdot 8^{\mathrm{ab}}$ & $22 \cdot 7$ & $5 \cdot 1^{\mathrm{ab}}$ & $21 \cdot 4$ & $3 \cdot 4^{\mathrm{ab}}$ & $37 \cdot 0$ & $2 \cdot 3^{\mathrm{b}}$ & $19 \cdot 6$ & $0.5^{\mathrm{a}}$ & 35.4 & $4 \cdot 6^{\mathrm{b}}$ \\
\hline Sum $n-3$ highly unsaturated fatty acids & 28.5 & $4 \cdot 5^{\mathrm{a}}$ & $21 \cdot 4$ & $4 \cdot 2^{\mathrm{a}}$ & $19 \cdot 8$ & $3 \cdot 6^{a}$ & $24 \cdot 0$ & $2 \cdot 2^{\mathrm{a}}$ & $18 \cdot 4$ & $0 \cdot 1^{\mathrm{a}}$ & $21 \cdot 7$ & $2 \cdot 5^{\mathrm{a}}$ \\
\hline
\end{tabular}

Superscript letters in the same row denote significantly different $(P \leq 0.05)$.

ND, not detected. 
Table 6. Fatty acid composition of HDL from sea bream fed the experimental diets for 12 weeks (Means and standard deviations; three samples from each tank, nine for each experimental diet)

\begin{tabular}{|c|c|c|c|c|c|c|c|c|c|c|c|c|}
\hline & \multicolumn{12}{|c|}{ Diet } \\
\hline & \multicolumn{2}{|c|}{$\begin{array}{c}100 \mathrm{FO} \\
\text { (g / } 100 \mathrm{~g} \text { fatty } \\
\text { acids) }\end{array}$} & \multicolumn{2}{|c|}{$\begin{array}{c}60 S O \\
\text { (g /100 g fatty } \\
\text { acids) }\end{array}$} & \multicolumn{2}{|c|}{$\begin{array}{c}60 \mathrm{RO} \\
\text { (g /100 g fatty } \\
\text { acids) }\end{array}$} & \multicolumn{2}{|c|}{$\begin{array}{c}60 \mathrm{LO} \\
\text { (g /100 g fatty } \\
\text { acids) }\end{array}$} & \multicolumn{2}{|c|}{$\begin{array}{c}80 \text { SO } \\
\text { (g /100 g fatty } \\
\text { acids) }\end{array}$} & \multicolumn{2}{|c|}{$\begin{array}{c}80 \mathrm{LO} \\
\text { (g /100 g fatty } \\
\text { acids) }\end{array}$} \\
\hline & Mean & SD & Mean & SD & Mean & SD & Mean & SD & Mean & SD & Mean & SD \\
\hline $14: 0$ & $1 \cdot 7$ & 0.2 & $1 \cdot 1$ & 0.2 & $1 \cdot 1$ & 0.1 & $1 \cdot 1$ & 0.1 & 0.9 & 0.1 & 0.9 & 0.1 \\
\hline $18: 0$ & $8 \cdot 3$ & 0.7 & 8.4 & 1.4 & $6 \cdot 3$ & 0.3 & 8.5 & 0.4 & 8.9 & 0.8 & $9 \cdot 0$ & $2 \cdot 1$ \\
\hline Sum saturated & $36 \cdot 1$ & $3 \cdot 4^{\mathrm{a}}$ & $33 \cdot 1$ & $5 \cdot 1^{\mathrm{ab}}$ & $26 \cdot 0$ & $1 \cdot 3^{b}$ & $31 \cdot 7$ & $2 \cdot 0^{\mathrm{ab}}$ & $32 \cdot 1$ & $2 \cdot 8^{a b}$ & $29 \cdot 8$ & $5 \cdot 1^{\mathrm{ab}}$ \\
\hline $16: 1 n-7$ & $2 \cdot 8$ & 0.2 & $2 \cdot 0$ & 0.3 & 1.5 & 0.8 & 1.9 & 0.1 & 1.5 & 0.1 & 1.5 & 0.1 \\
\hline $18: 1 n-9$ & $12 \cdot 2$ & $0.9^{a}$ & $15 \cdot 1$ & $1.6^{\mathrm{b}}$ & $21 \cdot 8$ & $0.7^{\mathrm{c}}$ & 14.9 & $0.7^{\mathrm{b}}$ & $14 \cdot 6$ & $0.5^{a b}$ & 14.9 & $0.8^{\mathrm{b}}$ \\
\hline $18: 1 n-7$ & $2 \cdot 4$ & 0.1 & $2 \cdot 3$ & 0.3 & $1 \cdot 8$ & 1.5 & $2 \cdot 0$ & 0.1 & 1.9 & 0.1 & 1.7 & 0.0 \\
\hline $20: 1 n-9$ & 0.77 & 0.1 & 0.8 & 0.0 & 1.3 & 0.1 & 0.8 & 0.1 & 0.8 & 0.1 & 0.8 & 0.1 \\
\hline $22: 1 n-11$ & 0.4 & 0.0 & 0.6 & 0.3 & 0.7 & 0.3 & 0.5 & 0.0 & 0.4 & 0.0 & 0.5 & 0.1 \\
\hline $22: 1 n-9$ & 0.3 & 0.0 & 0.3 & 0.0 & 0.5 & 0.3 & 0.2 & 0.0 & 0.3 & & 0.3 & \\
\hline $20: 2 n-6$ & 0.2 & 0.1 & 0.8 & 0.1 & 0.6 & 0.1 & 0.2 & 0.2 & 1.0 & 0.1 & 0.4 & 0.0 \\
\hline $20: 4 n-6$ & 1.7 & $0 \cdot 1^{a}$ & 1.0 & $0.4^{b c}$ & 1.5 & $0.2^{a b}$ & 1.3 & $0.0^{b}$ & 0.8 & $0.4^{b c}$ & $1 \cdot 2$ & $0.1^{\mathrm{bc}}$ \\
\hline $22: 4 n-6$ & $1 \cdot 3$ & 0.9 & 0.9 & 0.0 & 0.6 & 0.5 & 0.9 & 0.4 & 0.9 & 0.0 & 0.9 & 0.4 \\
\hline Sum $n-6$ & $6 \cdot 1$ & $1 \cdot 3^{\mathrm{a}}$ & $17 \cdot 2$ & $0.8^{\mathrm{b}}$ & $11 \cdot 2$ & $1 \cdot 1^{\mathrm{c}}$ & $9 \cdot 2$ & $0.5^{c}$ & $22 \cdot 8$ & $1 \cdot 3^{d}$ & $10 \cdot 8$ & $1 \cdot 3^{\mathrm{c}}$ \\
\hline $18: 3 n-3$ & 0.2 & $0.0^{\mathrm{a}}$ & 0.9 & $0.2^{\mathrm{b}}$ & $1 \cdot 3$ & $0.2^{b}$ & $7 \cdot 2$ & $1 \cdot 5^{\mathrm{cd}}$ & $1 \cdot 2$ & $0.1^{\mathrm{b}}$ & $10 \cdot 8$ & $2 \cdot 1^{d}$ \\
\hline $20: 4 n-3$ & 0.8 & 0.3 & 0.5 & 0.1 & 0.9 & 0.4 & 0.8 & 0.1 & 0.4 & 0.0 & 0.8 & 0.1 \\
\hline $20: 5 n-3$ & $13 \cdot 1$ & $1 \cdot 2^{\mathrm{a}}$ & 8.0 & $2 \cdot 0^{b c}$ & 9.7 & $0.7^{\mathrm{b}}$ & 9.2 & $0.6^{\mathrm{b}}$ & $6 \cdot 1$ & $0.7^{b c}$ & 7.0 & $1.0^{\mathrm{C}}$ \\
\hline $22: 5 n-3$ & $3 \cdot 6$ & 0.4 & $2 \cdot 7$ & 0.7 & $3 \cdot 3$ & 0.6 & $2 \cdot 7$ & 0.3 & $2 \cdot 1$ & 0.4 & $2 \cdot 0$ & 0.1 \\
\hline $22: 6 n-3$ & 21.4 & $1 \cdot 8^{\mathrm{a}}$ & $17 \cdot 3$ & $4 \cdot 0^{a}$ & $20 \cdot 0$ & $1 \cdot 2^{\mathrm{a}}$ & $19 \cdot 0$ & $0.8^{a}$ & $16 \cdot 1$ & $2 \cdot 4^{\mathrm{a}}$ & $18 \cdot 3$ & $2 \cdot 2^{\mathrm{a}}$ \\
\hline Sum $n-3$ & $39 \cdot 0$ & $3 \cdot 7^{\mathrm{a}}$ & $29 \cdot 2$ & $6 \cdot 7^{\mathrm{ab}}$ & $35 \cdot 3$ & $2 \cdot 5^{\mathrm{ab}}$ & $38 \cdot 8$ & $2 \cdot 8^{a}$ & $25 \cdot 8$ & $3 \cdot 2^{b}$ & $39 \cdot 0$ & $5 \cdot 3^{a}$ \\
\hline Sum $n-3$ highly unsaturated fatty acids & $38 \cdot 8$ & $3 \cdot 6^{\mathrm{a}}$ & $28 \cdot 3$ & $6 \cdot 5^{b}$ & 33.9 & $2 \cdot 5^{\mathrm{ab}}$ & $31 \cdot 6$ & $1 \cdot 4^{\mathrm{ab}}$ & $24 \cdot 6$ & $3 \cdot 1^{\mathrm{b}}$ & $28 \cdot 1$ & $3 \cdot 2^{\mathrm{b}}$ \\
\hline
\end{tabular}

Superscript letters in the same row denote significantly different $(P \leq 0.05)$.

ND, not detected.

comparison to the VLDL fraction. High levels of 16:0 fatty acids were also found in the HDL fraction.

\section{Discussion}

HDL was the mayor lipoprotein found in sea bream, confirming that this is the main lipoprotein involved in lipid transport as it also occurs in other species (Nelson \& Shore, 1974; Chapman et al. 1980; Babin \& Vernier, 1989; Santulli et al. 1989; Iijima et al. 1990; Lie et al. 1993). Such a predominance of HDL might be the consequence of a lower degradation of this fraction in comparison with other lipoproteins, a faster degradation of VLDL by lipoprotein lipase or an increased synthesis in liver and intestine (Léger, 1988; Iijima et al. 1990).

The lipid and protein composition of each lipoprotein fraction in sea bream was similar to that of other teleost fish. Thus, the chemical composition of HDL was characterised by a high content of protein and phospholipids, particularly phosphatidylcholine (Chapman, 1980; Lie et al. 1993). HDL and LDL were the two main lipoproteins involved in cholesterol transport in sea bream. Although the highest cholesterol contents were found in the LDL fraction, in agreement with other species (Farrell \& Munt, 1983; Farrell et al. 1986; Lie et al. 1993; Torstensen et al. 2000), the main bulk of plasma cholesterol was transported by HDL, which was the more abundant lipoprotein in sea bream.

Despite this, VLDL was found to be present in minor amounts in the serum of other species (Santulli et al. 1997).
In sea bream plasma, the content of VLDL was found to be higher than that of LDL, reflecting the VLDL synthesis observed by electron microscopy in the enterocytes of this fish (Caballero et al. 2003). The VLDL fraction, rich in TAG as in other fish (McKay et al. 1985; Fainaru et al. 1988; Babin \& Vernier, 1989; Torstensen et al. 2001), is implicated mainly in the transport of TAG to various tissues.

Interestingly, dietary fatty acids affected the lipid class composition of the lipoproteins. Thus, substitution of $80 \%$ fish oil by either soyabean or linseed oil raised the cholesterol content of the HDL and LDL. Although the fish-oil diets contained a higher proportion of saturated fatty acids $(27.9 \% \mathrm{v}$. $18.6 \%$ and $16.3 \%$ in the vegetable-oil diets), which are reported to increase plasma cholesterol level (Hayes et al. 1997), this effect may be reduced in fish in view of their lower digestibility (about $85 \%$ in sea bream) in comparison with $n-3$ HUFA ( $95 \%$ in sea bream). The elevation in cholesterol caused by the reduction in dietary fish oil could instead be related to the high $n$-3 HUFA content of this oil $(17.96 \%$ in fish-oil diets $v .6 .9 \%$ and $7.4 \%$, in vegetable-oil diets), in view of the high correlations found between the dietary $n-3$ HUFA and the HDL-cholesterol or LDL-cholesterol (Fig. 5(A), (B)). Despite the lack of studies in fish, considerable data are available on the effects of $n-3$ PUFA, with eighteen or more carbon atoms and two or more double bonds, on the plasma levels of cholesterol in mammals. Thus, in human subjects, the hypocholesterolaemic effect of fatty acids follows the pattern $n-3$ PUFA less than $n-6$ PUFA less than saturated fatty acids (Williams, 1998). As in 

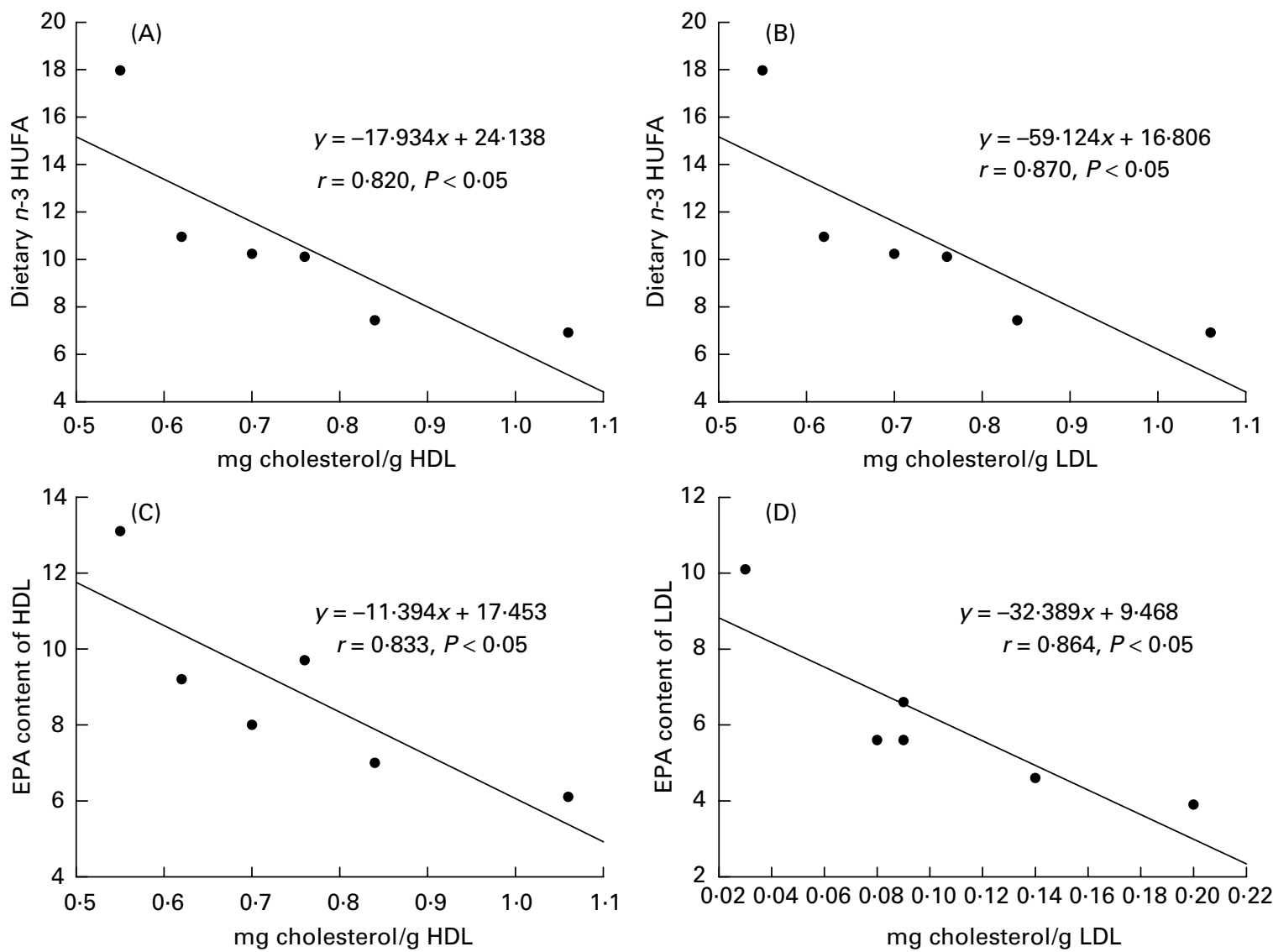

Fig. 5. Relationships between dietary $n$-3 highly unsaturated fatty acids (HUFA) and cholesterol level in HDL and LDL fractions ((A), (B)). Relationships between EPA content in HDL and LDL and the cholesterol level of those fractions ((C), (D)). Each point represents the dietary group.

mammals, dietary $n$ - 3 HUFA could, in the present experiment, enhance the activity of the enzyme lecithin:cholesterol acyltransferase located in the HDL (Thornburg et al. 1995; Parks et al. 2000), which catalyses the transfer of a fatty acid from phosphatidylcholine to cholesterol to form sterol esters, as the cholesterolsterol esters ratios in HDL were doubled in fish fed $80 \%$ fish-oil substitution with vegetable oils than in those fed $100 \%$ fish oil. In addition, fish fed fish oil had a lower content of phosphatidylcholine, another substrate for lecithin:cholesterol acyltransferase.

In addition, significant inverse relationships were also found between EPA and HDL-cholesterol or LDL-cholesterol (Fig. 5(C), 5(D)). Spady (1993) described, in rats, how high levels of EPA and DHA decreased the LDLcholesterol level by enhancing the activity of LDL-receptors in the liver. In turn, Tripodi et al. (1991) reported that the high affinity of the LDL fraction towards its liver receptors induced hypocholesterolaemia in rat fed those fatty acids. Similarly, in sea bream fed the fish-oil diet, with a higher content of these fatty acids, there was a reduction in LDL-cholesterol. As LDL receptors are proteins located in cell membranes, their function may be affected by the fatty acid composition of the membrane. Changes in the lipid composition of the membrane can induce structural and functional alterations in specific receptors (Gurr \& Harwood, 1991).
The TAG content of all the lipoprotein fractions was also reduced by feeding fish oil. In human subjects, a high dietary content of $n-3$ PUFA reduces VLDL-TAG levels via a decrease in TAG synthesis in the liver (Harris et al. 1983; Berge et al. 1999).

The fatty acid composition of the VLDL was more readily affected by the diet than that of HDL, which could be related to the higher TAG content of the former lipoprotein as, in fish, neutral lipids are easily influenced by dietary fatty acids (Brodtkorb et al. 1997; Olsen \& Henderson, 1997). In addition, the specific fatty acid composition of the lipoprotein would be related to the functional differences and the different metabolism and site of synthesis of the lipoproteins.

Finally, HDL was characterised by high levels of $22: 6 n-3$, independent of dietary fatty acids. These results are in accordance with those of other studies (Lie et al. 1993; Torstensen et al. 2000) and suggest that HDL, the dominant lipoprotein in sea bream, is mainly implicated in the transport of DHA to the tissues (Brodtkorb et al. 1997).

In conclusion, dietary fish oil substitution by up to $60 \%$ of soyabean, linseed or rapeseed oil did not markedly affected lipoprotein composition, whereas $80 \%$ substitution by soyabean or linseed oil increased plasma cholesterol and TAG concentrations owing to the low $n-3$ HUFA content of these diets. 


\section{Acknowledgements}

The present study was supported by the European Union under Quality of Life and Management of Living Resources through project Q5RS-2000-30058 RAFOA, which gave a partial (four diets) grant to the research, and by the Spanish government under the FEDER programme, project 1FD1997-1774, which granted the rest of the diets.

\section{References}

Auwerx J, Leroy P \& Schoonjans K (1992) Lipoprotein lipase: recent contributions from molecular biology. Crit Rev Clin Lab Sci 29, 243-268.

Babin PJ \& Vernier JM (1989) Plasma lipoproteins in fish. J Lipid Res 30, 467-489.

Bell JG, McGhee F, Campbell PJ \& Sargent JR (2003) Rapeseed oil as an alternative to marine fish oil in diets of post-smolt Atlantic salmon (Salmo salar): changes in flesh fatty acid composition and effectiveness of subsequent fish oil "wash out". Aquaculture 218, 515-528.

Berge RK, Madsen L, Vaaganes H, Tronstad KJ, Gottlicher M \& Rustan AC (1999) In contrast with docosahexaenoic acid, eicosapentanoic acid and hypolipidaemic derivatives decrease hepatic synthesis and secretion of triacylglycerol by decreased diacylglycerol acyltransferase activity and stimulation of fatty acid oxidation. Biochem J 343, 191-197.

Black D, Mackie SG \& Skinner ER (1985) A lecithin:cholesterol acyltransferase-like activity in the plasma of rainbow trout. Biochem Soc Trans 13, 143-144.

Brodtkorb BT, Rosenlund G \& Lie Ø (1997) Effects of 20:5n-3 and $22: 6 n-3$ on tissue lipid composition in juvenile Atlantic salmon, Salmo salar, - with emphasis on brain and eye. Aquac Nutr 3, 175-187.

Brown MS \& Goldstein JL (1997) The SREBP pathway: regulation of cholesterol metabolism by proteolysis of a membrane-bound transcription factor. Cell 89, 331-340.

Caballero MJ, Gallardo G, Robaina L, Montero D, Fernández A \& Izquierdo M (2006) Vegetable lipid sources affect in vitro biosynthesis of triacylglycerols and phospholipids in the intestine of sea bream (Sparus aurata). Br J Nutr 95, 448-454.

Caballero MJ, Izquierdo MS, Kjørsvik E, Montero D, Socorro J, Fernández AJ \& Rosenlund G (2003) Morphological aspects of intestinal cells from gilthead sea bream (Sparus aurata) fed diets containing different lipid sources. Aquaculture 225, 325-340.

Caballero MJ, Obach A, Rosenlund G, Montero D, Gisvold M \& Izquierdo MS (2002) Impact of different dietary lipid sources on growth, lipid digestibility, tissue fatty acid composition and histology of rainbow trout, Oncorhynchus mykiss. Aquaculture 214, $253-271$.

Chapman MJ (1980) Animal lipoproteins: chemistry, structure, and comparative aspects. J Lipid Res 21, 789-853.

Christie WW (1982) Lipid analysis. Oxford: Pergamon Press.

Fainaru M, Schafer Z, Gavish D, Harel A \& Schwartz M (1988) Interactions between human and carp (Cyprinus carpio) low density lipoproteins (LDL) and LDL receptors. Comp Biochem Physiol 91B, $331-338$.

Farrell AP \& Munt B (1983) Cholesterol levels in the blood of Atlantic salmonids. Comp Biochem Physiol 75A, 239-242.

Farrell AP, Saunders LR, Freeman HC \& Mommsen TP (1986) Artherosclerosis in Atlantic salmon. Effect of dietary cholesterol and maturation. Atherosclerosis 6, 453-461.

Folch J, Lees M \& Sloane-Stanley GH (1957) A simple method for the isolation and purification of total lipids from animal tissues. J Biol Biochem 226, 497-509.
Food and Agriculture Organization (1997) Review of the State of the World Aquaculture. FAO Fisheries Circular No. 886. Rev. 1. Rome: FAO.

Fox C (1990) Studies on polyunsaturated fatty acid nutrition in larvae of marine fish-the herring. L. PhD Thesis, University of Stirling.

Gurr MI \& Harwood JL (1991) Lipid Biochemistry. An Introduction, 4th ed, London: Chapman \& Hall.

Harris WS, Connor WE \& McMurry MP (1983) The comparative reductions of the plasma lipids and lipoproteins by dietary polyunsaturated fats: salmon oil versus vegetable oils. Metabolism 32, 179-184.

Hayes KC, Khosla P, Hajri T \& Pronczuk A (1997) Saturated fatty acids and LDL receptor modulation in humans and monkeys. Prostaglandins Leukot Essent Fatty Acids 57, 411-418.

Iijima N, Gotou T \& Kayama M (1995) Isolation and characterization of serum lipoproteins in red sea bream. Fish Sci 61, 297-303.

Iijima N, Ueki T \& Yoshitake S (1990) Isolation and characterization of carp plasma lipoproteins. Nippon Suisan Gakkaishi 57, $1113-1122$.

Izquierdo MS, Montero D, Robaina L, Caballero MJ, Rosenlund G \& Ginés R (2005) Alterations in fillet fatty acid profile and flesh quality in gilthead sea bream (Sparus aurata) fed vegetable oils for a long term period. Recovery of fatty acid profiles by fish oil feeding. Aquaculture 250, 431-444.

Izquierdo MS, Obach A, Arantzamendi L, Montero D, Robaina L \& Rosenlund G (2003) Dietary lipid sources for sea bream and sea bass: growth performance, tissue composition and flesh quality. Aquacult Nutr 9, 397-407.

Izquierdo MS, Watanabe T, Takeuchi T, Arakawa T \& Kitajima C (1990) Optium EFA levels in artemia to meet the EFA requirements of red sea bream (Pagrus major). In The Current Status of Fish Nutrition in Aquaculture, pp. 221-232 [M Takeda and T Watanabe, editors]. Tokyo: University Fisheries.

Léger C (1988) Digestion, absorption and transport of lipids. In Nutrition and Feeding in Fish, pp. 299-331 [CB Cowey, AM Mackie and JG Bell, editors]. London: Academic Press.

Lie Ø, Sandvin A \& Waagbø R (1993) Influence of dietary fatty acids on the lipid composition of lipoproteins in farmed Atlantic salmon (Salmo salar). Fish Physiol Biochem 12, 249-260.

Lie $\varnothing$, Sandvin A \& Waagbø R (1994) Transport of alpha-tocopherol in Atlantic salmon (Salmo salar) during vitellogenesis. Fish Physiol Biochem 13, 241-247.

Lowry OH, Rosebrough NJ, Farr AL \& Randall RJ (1951) Protein measurement with folin phenol reagent. J Biol Chem 193, 265-275.

McKay MC, Lee RF \& Smith MAK (1985) The characterization of the plasma lipoproteins of the channel catfish, Ictalurus punctatus. Physiol Zool 58, 693-704.

Montero D, Robaina L, Caballero MJ, Ginés R \& Izquierdo MS (2005) Growth, feed utilization and flesh quality of European sea bass (Dicentrarchus labrax) fed diets containing vegetable oils: a time-course study on the effect of a re-feeding period with a $100 \%$ fish oil diet. Aquaculture 248, 121-134.

Montero D, Tort L, Izquierdo MS, Socorro J, Robaina LE, Vergara JM \& Fernández-Palacios H (1996) Effect of alpha-tocopherol and n-3 HUFA deficient diets on blood cells, selected immune parameters and proximate body composition of gilthead seabream (Sparus aurata). In Modulators of Immune Response. The Evolutionary Trail 9, pp. 251-266 [JS Stolen, TC Fletcher, CJ Secombes, JL Zelikoff, L Twerdock and DP Anderson, editors]. Fair Haven, CT: SOS Publications.

National Research Council (1993) Nutrient Requirements of Fish. Washington, DC: National Academy Press.

Nelson GJ \& Shore VG (1974) Characterization of the serum high density lipoproteins of pink salmon. J Biol Chem 259, 536-542.

Olsen RE \& Henderson RJ (1997) Muscle fatty acid composition and oxidative stress indices of Arctic charr, Salvelinus alpinus (L.), in 
relation to dietary polyunsaturated fatty acid levels and temperature. Aquac Nutr 3, 227-238.

Parks JS, Huggins KW, Gebre AK \& Burleson ER (2000) Phosphatidylcholine fluidity and structure affect lecithin:cholesterol acyltransferase activity. J Lipid Res 4, 41, 546-553.

Regost C, Arzel J, Robin J, Rosenlund G \& Kaushik J (2003) Total replacement of fish oil by soybean oil with return to fish oil in turbot (Psetta maxima). I. Growth performance, flesh fatty acid profile, and lipid metabolism. Aquaculture 217, 465-482.

Rønnestad I, Finn RN, Lein I \& Lie Ø (1995) Compartmental changes in the contents of total lipid, lipid classes and their associated fatty acids in developing yolk-sac larvae of Atlantic halibut, Hippoglossus hippoglossus (L.). Aquac Nutr 1, 119-130.

Santulli A, Curatolo A, Modica A \& D'Amelio A (1989) Serum lipoproteins of sea bass (Dicentrarchus labrax L.). Purification and partial characterization by density gradient ultracentrifugation and agarosa column chromatography. Comp Biochem Physiol 94B, 613-619.

Santulli A, Messina CM \& D'Amelio V (1997) Variations of lipid and apolipoprotein content in lipoproteins during fasting in European sea bass (Dicentrarchus labrax). Comp Biochem Physiol 118A, 1233-1239.

Sheridan MA (1988) Lipid dynamics in fish: aspects of absorption, transportation, deposition and mobilization. Comp Biochem Physiol 90B(4), 679-690.

Sheridan MA, Friedlander JKL \& Allen WV (1985) Chylomicra in the serum of postprandrial steel head trout (Salmo gairdneri). Comp Biochem Physiol 81B, 281-284.
Sire MF, Lutton C \& Vernier JM (1981) New views on intestinal absorption of lipids in teleostean fishes: an ultrastructural and biochemical study in the rainbow trout. J Lipid Res 22, 81-94.

Sokal RR \& Rolf FJ (1995) Biometry. The Principles and Practice of Statistics in Biological Research, 3rd ed, New York: WH Freeman.

Spady DK (1993) Regulatory effects of individual n-6 and n-3 polyunsaturated fatty acids on LDL transport in the rat. J Lipid Res $\mathbf{3 4}$ $1337-1346$.

Thornburg JT, Parks JS \& Rudel LL (1995) Dietary fatty acid modification of HDL phospholipid molecular species a lecithin:cholesterol acyltransferase reactivity in cynomolgus monkeys. J Lipid Res 36, 277-289.

Torstensen BE, Lie $\varnothing$ \& Frøyland L (2000) Lipid metabolism and tissue composition in Atlantic salmon (Salmo salar L.). Effects of capelin oil, palm oil, and oleic acid-enriched sunflower oil as dietary lipid sources. Lipids 35, 653-663.

Torstensen BE, Lie $\varnothing$ \& Hamre K (2001) A factorial experimental design for investigation of effects of dietary lipid content and pro- and antioxidants on lipid composition in Atlantic salmon (Salmo salar) tissues and lipoproteins. Aquacult Nutr 7, 265-276.

Tripodi A, Loria P, Dilengite MA \& Carulli N (1991) Effect of fish oil and coconut oil diet on the LDL receptor activity of rat liver plasma membranes. Biochem Biophys Acta 1083, 298-304.

Warnick GR, Cheung MC \& Albers JJ (1979) Comparison of current methods for high density lipoprotein cholesterol quantitation. Clin Chem 25, 596-604.

Williams CM (1998) Dietary interventions affecting chylomicron and chylomicron remnant clearance. Atherosclerosis 141, 87-92. 